\title{
Pengaruh Model Pembelajaran Berbasis Masalah terhadap Kemampuan Menulis Karangan Argumentasi Siswa Kelas IX SMP Muhammadiyah 1 Kota Tangerang
}

\author{
Supyan Sori \\ Universitas Muhammadiyah Tangerang \\ Email: sopyanyahut@gmail.com
}

\begin{abstract}
APA Citation: Sori, S. (2021). Pengaruh Model Pembelajaran Berbasis Masalah terhadap Kemampuan Menulis Karangan Argumentasi Siswa Kelas IX SMP Muhammadiyah 1 Kota Tangerang. Silampari Bisa: Jurnal Penelitian Pendidikan Bahasa Indonesia, Daerah, dan Asing, 4(2), 257-266. https://doi.org/10.31540/silamparibisa.v4i2.1361
\end{abstract}

\begin{abstract}
Abstrak
Tujuan penelitian ini untuk mengetahui pengaruh model pembelajaran berbasis masalah terhadap kemampuan menulis karangan argumentasi siswa kelas IX SMP Muhammadiyah 1 Kota Tangerang. Metode yang digunakan dalam penelitian ini adalah metode quasi eksperimen dengan melakukan pretes dan postes dua kelompok. Jenis metode penelitian eksperimen ini menggunakan desain penelitian nonequivalent control group design, dimana kelas eksperimen yang diberi perlakuan dan kelas kontrol tidak diberi perlakuan. Teknik pengumpulan data menggunakan tes dalam bentuk tes essay berupa unjuk kerja menulis karangan argumentasi. Teknik analisis data dimulai dari uji normalitas, uji homogenitas, dan dilanjutkan uji hipotesis. Hasil penelitian menunjukkan bahwa diperoleh data post test atau tes akhir yang kemudian dianalisis dengan menggunakan uji t dua pihak, memberikan hasil bahwa siswa yang diberikan perlakuan pembelajaran model pembelajaran berbasis masalah lebih mengalami peningkatan dibandingkan dengan siswa yang tidak diberikan strategi pembelajaran PBM. Hal ini dapat dilihat dari hasil perhitungan, bahwa nilai thitung $>$ nilai tabel dengan perolehan thitung sebesar 0,94 sedangkan untuk ttabel sebesar 2,0084. Hal ini membuktikan hipotesis diterima yaitu terdapat perbedaan kemampuan menulis karangan argumentasi siswa antara siswa yang diberi model pembelajaran berbasis masalah dengan siswa yang tidak diberikan model pembelajaran berbasis masalah.
\end{abstract}

Kata kunci: pengaruh, model pembelajaran berbasis masalah, kemampuan menulis karangan argumentasi, siswa

\section{The Effect of Problem-Based Learning Model on the Ability to Write Argumentative Essays for Class IX Students of SMP Muhammadiyah 1 Kota Tangerang}

\begin{abstract}
The purpose of this study was to determine the effect of the problem-based learning model on the ability to write argumentative essays for class IX students of SMP Muhammadiyah 1 Tangerang City. The method used in this study is a quasi-experimental method by
\end{abstract}




\section{Supyan Sori}

Pengaruh Model Pembelajaran Berbasis Masalah terhadap Kemampuan Menulis Karangan

Argumentasi Siswa Kelas IX SMP Muhammadiyah 1 Kota Tangerang

conducting a pretest and posttest in two groups. This type of experimental research method uses a nonequivalent control group design, where the experimental class is treated and the control class is not treated. The data collection technique used a test in the form of an essay test in the form of performance in writing an argumentative essay. The data analysis technique starts from the normality test, homogeneity test, and continues to test the hypothesis. The results showed that post-test or final test data were obtained which were then analyzed using a two-party t-test, giving the result that students who were given treatment with problem-based learning models experienced more improvement than students who were not given PBM learning strategies. This can be seen from the calculation results, that the value of tcount $>$ ttable value with the acquisition of tcount of 0.94 while for ttable of 2.0084. This proves that the hypothesis is accepted, namely that there are differences in students' ability to write argumentative essays between students who are given a problem-based learning model and students who are not given a problem-based learning model.

Keywords: effect, problem-based learning model, ability to write argumentative essays, students

\section{A. Pendahuluan}

Belajar bahasa Indonesia merupakan upaya peningkatan diri atau perubahan diri melalui berbagai proses dan latihan bukan merupakan peristiwa secara kebetulan. Kebiasaan belajar bahasa Indonesia yang baik tidak dapat dibentuk dalam waktu yang singkat. Akan tetapi, perlu dikembangkan secara bertahap. Kebiasaan belajar bahasa Indonesia yang baik pada intinya dibutuhkan rencana kegiatan belajar yang jelas dan adanya disiplin diri yang kuat untuk menepati apa yang telah direncanakan.

Kurikulum Tingkat Satuan Pendidikan (KTSP), pembelajaran bahasa Indonesia bertujuan agar siswa terampil berbahasa dan mampu berkomunikasi, baik secara lisan maupun tulisan. Kemampuan berbahasa tersebut dibedakan atas empat aspek keterampilan, yaitu keterampilan mendengarkan, berbicara, membaca, dan keterampilan menulis (Susanto, 2015:243). Salah satu dari keempat aspek keterampilan berbahasa yang bersifat produktif tersebut adalah keterampilan menulis.

Keterampilan menulis merupakan keterampilan melahirkan pikiran atau gagasan dengan tulisan. Dengan menulis, kita bisa menyampaikan ide-ide atau perasaan ke dalam bentuk tulisan. Melalui menulis kita dapat mengekspresikan berbagai macam ekspresi yang kita rasakan seperti perasaan senang, sedih, kecewa, putus asa, menyerah, menyesal atau yang lainnya. Ekspresi yang kita rasakanlah yang bisa kita tuangkan kedalam sebuah karangan.

Menulis merupakan salah satu dari empat keterampilan berbahasa yang mendasar. Di antara keterampilan berbahasa yang lain, menulis merupakan salah satu keterampilan yang tidak dikuasai oleh setiap orang, apalagi menulis dalam konteks akademik, seperti menulis esai, karya ilmiah, laporan penelitian, dan sebagainya (Zainurrahman, 2013:2). Dari pendapat tersebut dapat disimpulkan bahwa menulis adalah salah satu keterampilan berbahasa yang tidak semua orang dapat menguasainya, karena di dalam menulis sangat dibutuhkan ide, gagasan, dan konsep yang akan ditulis sehingga dapat dipahami oleh pembaca. Menulis merupakan suatu keterampilan berbahasa yang dipergunakan untuk berkomunikasi secara tidak langsung, tidak secara tatap muka dengan orang lain (Hudhana \& Sulaeman, 2019). Sebagai bentuk keterampilan berbahasa, menulis merupakan kegiatan yang bersifat mengungkapkan gagasan, buah pikiran, dan perasaan 


\section{Supyan Sori}

Pengaruh Model Pembelajaran Berbasis Masalah terhadap Kemampuan Menulis Karangan Argumentasi Siswa Kelas IX SMP Muhammadiyah 1 Kota Tangerang

kepada orang lain (Hasibuan \& Hafrison, 2020). Oleh karena itulah, menulis merupakan suatu kegiatan produktif dan ekspresif (Tarigan, 2008:3). Ishak (2014:161) menjelaskan, "Menulis merupakan jenis pekerjaan mulia yang memerlukan pikiran kreatif dan produktif, karena ulasan yang bermula dari sebuah gagasan hasil bacaan akan menjadi sebuah masukan bagi pembaca. Kegiatan menulis ini bisa dalam bentuk karangan fiksi dan karangan nonfiksi.

Selanjutnya pada kegiatan mengarang, Suparno dan Yunus (2012) dan Dalman (2014:86) juga mengemukakan bahwa karangan pada hakikatnya bertujuan mengungkapkan atau menyampaikan gagasan dengan menggunakan bahasa tulis. Dari pengertian ini karangan adalah menuangkan atau menyampaikan suatu gagasan dengan menggunakan media tulisan. Mengarang adalah menuangkan buah pikiran ke dalam bahasa tulis melalui kalimat-kalimat yang dirangkai secara utuh, lengkap, dan jelas sehingga buah pikiran tersebut dapat dikomunikasikan kepada pembaca (Bryne dalam Saddhono, 2014:8). Berdasarkan beberapa pendapat di atas dapat disimpulkan bahwa mengarang adalah menuangkan pikiran secara utuh dalam bentuk bahasa tulis sehingga menajdi kalimat yang jelas dan dapat memberikan informasi kepada pembaca. Cara penuangan tulisan tersebut dengan cara membuat rangkaian kalimat-kalimat yang baik dan dapat dipahami oleh pembaca. Karangan yang baik adalah karangan yang dituangkan melalui gagasan pemikiran yang jelas.

Salah satu jenis tulisan yang diajarkan di sekolah yaitu tulisan argunemntasi. Menulis karangan argumentasi yaitu menulis tulisan yang ditulis bertujuan meyakinkan pembaca untuk menyetujui fakta, norma, alasan, dalih, dan kesimpulan dari suatu pandangan dari bukti-bukti yang ilmiah (Lakhsmi, 2008 dalam Mulyati, 2019:71). Untuk itu, karena proses menulis argumentasi ini membutuhkan usaha yang keras dari guru karena siswa harus mampu melalui proses menulis bukan saja menuangkan ide, tetapi bagaimana siswa mampu meyakinkan pembaca dengan bukti ilmiah dan bahasa yang persuasif. Maka, diprediksi model pembelajaran berbasis masalah mampu mempengaruhi kemampuan menulis karangan argumentasi siswa.

Model pembelajaran berbasis masalah ini melatih dan mengembangkan kemampuan untuk menyelesaikan masalah yang berorientasi pada masalah autentik dari kehidupan aktual siswa, untuk merangsang kemampuan berpikir tingkat tinggi. Model pembelajaran berbasis masalah atau lebih dikenal model pembelajaran Problem Based Learning (PBL) merupakan pendekatan yang efektif untuk pengajaran proses berpikir tingkat tinggi. Pembelajaran ini membantu siswa untuk memproses informasi yang sudah jadi dalam benaknya dan menyusun pengetahuan mereka sendiri tentang dunia social dan sekitarnya (Trianto, 2007:68). Pembelajaran berbasis masalah juga didefinisikan oleh Tan (dalam Rusman, 2012:232) merupakan penggunaan berbagai macam kecerdasan yang diperlukan untuk melakukan konfirmasi terhadap tantangan dunia nyata, kemampuan untuk menghadapi sesuatu dengan kompleksitas yang ada.

Menurut Tan (2003) dan Shoimin (2014) pembelajaran berbasis masalah merupakan inovasi dalam pembelajaran karena dalam PBM kemampuan berpikir siswa betul-betul di optimalisasikan melalui proses kerja kelompok atau tim yang sistematis, sehingga siswa dapat memberdayakan, mengasah, menguji, dan mengembangkan kemampuan berpikirnya secara berkesinambungan. Pada kenyataannya, tidak semua guru memahami konsep PBM tersebut, baik disebabkan oleh kurangnya keinginan dan motivasi untuk meningkatkan kualitas keilmuan maupun karena kurangnya dukungan sistem untuk meningkatkan kualitas keilmuan

Silampari Bisa: Jurnal Penelitian Pendidikan Bahasa Indonesia, Daerah, dan Asing

Vol. 4, No. 2, 2021 


\section{Supyan Sori}

Pengaruh Model Pembelajaran Berbasis Masalah terhadap Kemampuan Menulis Karangan Argumentasi Siswa Kelas IX SMP Muhammadiyah 1 Kota Tangerang

tenaga pendidik. Berdasarkan hal tersebut, maka perlu kiranya ada sebuah bahan kajian yang mendalam tentang apa dan bagaimana pembelajaran berbasis masalah ini untuk selanjutnya diterapkan dalam sebuah proses pembelajaran, sehingga dapat memberi masukan, khususnya kepada para guru tentang Pembelajaran Berbasis Masalah, yang menurut Tan (2003) merupakan pendekatan pembelajaran yang relevan dengan tuntutan abad ke-21 dan umumnya kepada para ahli dan praktisi pendidikan yang memusatkan perhatiannya pada pengembangan dan inovasi sistem pembelajaran.

Pembelajaran berbasis masalah, bukan hanya terbukti mampu berpengaruh dalam meningkatkan kemampuan menulis teks deskripsi siswa (Sakila, 2019) dan kemampuan menulis karangan narasi (Iman, 2018)), tetapi berpengaruh dalam meningkatkan kemampuan menulis teks prosedur kompleks (Frince S, 2018). Untuk itu, dalam penelitian ini akan membuktikan hipotesis ada pengaruh model pembelajaran berbasis masalah terhadap kemampuan menulis karangan argumentasi siswa kelas IX SMP Muhammadiyah 1 Kota Tangerang.

\section{B. Metode Penelitian}

Metode penelitian adalah suatu cara atau prosedur yang dipergunakan untuk melakukan penelitian sehingga mampu menjawab rumusan masalah dan tujuan penelitian. Metode penelitian pada dasarnya juga merupakan cara ilmiah untuk mengumpulkan data dengan tujuan dan kegunaan tertentu. Cara ilmiah berarti kegiatan penelitian itu didasarkan pada ciri-ciri keilmuan yaitu rasional, empiris, dan sistematis (Sugiyono, 2011). Dalam metode kuantitatif peneliti menggunakan penelitian Quasi Eksperimen dengan jenis Nonequivalent Control Group Desaign. Peneliti menggunakan dua kelompok yang terdiri atas kelompok eksperimental yang diberi perlakuan dengan menggunakan model pembelajaran berbasis masalah dan kelompok kontrol yang tidak diberi perlakuan/konvensional. Pemilihan kelompok eksperimen maupun kelompok kontrol tidak dipilih secara acak (random). Hasil pre test yang baik bila nilai kelompok eksperimen tidak berbeda secara signifikasi, maka rancangan ini dapat digunakan sebagai berikut:

Tabel 1. Rancangan Penelitian

\begin{tabular}{lcccc}
\hline \multicolumn{1}{c}{ Kelompok } & & Pre Test & Perlakuan & Post Test \\
\hline Eksperimental & & $Y_{E}$ & $\mathrm{X}$ & $Y_{E}$ \\
\hline Kontrol & & $Y_{K}$ & - & $Y_{K}$ \\
\hline Keterangan: & $Y_{E}$ & = Data hasil pre tes/post test kelas eksperimental \\
& $Y_{K}$ & $=$ & Data hasil pre tes/post test kelas kontrol \\
& $\mathrm{X}$ & = Perlakuan yang dieksperimental
\end{tabular}

Teknik pengumpulan data yang umum digunakan dalam penelitian adalah: tes, wawancara, kuesiner, dan observasi (Sugiyono, 2011 dalam Sulaeman \& Goziyah, 2019:18). Teknik pengumpulan dalam penelitian ini adalah dengan tes. Tes adalah pengukuran yang sudah direncanakan oleh guru untuk melihat sejauh mana kemampuan yang dimiliki masing-masing siswa dengan tujuan yang telah ditentukan. Tes yang digunakan oleh peneliti dalam penelitian ini adalah tes berbentuk essay.

Silampari Bisa: Jurnal Penelitian Pendidikan Bahasa Indonesia, Daerah, dan Asing Vol. 4, No. 2, 2021 


\section{Supyan Sori}

Pengaruh Model Pembelajaran Berbasis Masalah terhadap Kemampuan Menulis Karangan Argumentasi Siswa Kelas IX SMP Muhammadiyah 1 Kota Tangerang

Tes yang akan dilakukan terbagi atas 2 bagian yaitu, 1) pre test yaitu tes yang diberikan sesudah melaksanakan pembelajaran tanpa memberikan perlakuan (tidak menggunakan model pembelajaran berbasis masalah). Kemudian, 2) post test yaitu tes yang diberikan sesudah melaksanakan pembelajaran dengan memberikan perlakuan (menggunakan model pembelajaran berbasis masalah). Teknik analisis data dalam penelitian ini menggunakan uji parametrik. Langkah-langkah analisis datanya yaitu uji normalitas, uji homogenitas, dan dilanjutkan uji t untuk menguji hipotesis statistik.

\section{Hasil Penelitian dan pembahasan}

1. Hasil Penelitian

a. Pengujian Persyaratan Analisis Data

1) Analisis Uji Normalitas Data Pre Test

Uji normalitas adalah uji untuk mengetahui apakah data yang diperoleh berasal dari sampel yang berdistribusi normal atau tidak. Dalam penelitian ini uji normalitas yang digunakan adalah Uji lillieforse. Berdasarkan data hasil penelitian, uji normalitas dari pre test kelas eksperimen dan kelas kontrol, diperoleh perhitungan sebagai berikut.

Tabel 2. Hasil Perhitungan Uji Normalitas Lillieforse

\begin{tabular}{ccccc}
\hline \multirow{2}{*}{ Kelas } & Pre-test & Post-test & \multirow{2}{*}{$L_{t}$} & \multirow{2}{*}{ Keterangan } \\
\cline { 2 - 3 } & $L_{h}$ & $L_{h}$ & & \\
\hline Experimen & $-0,054$ & 0,0541 & 0,177 & Normal \\
\hline Kontrol & $-0,595$ & $-0,117$ & 0,177 & Normal \\
\hline
\end{tabular}

Berdasarkan tabel di atas, dapat di lihat bahwa $L h$, dari kedua kelas kurang dari $L t$, maka dari itu dapat disimpulkan bahwa data adalah normal.

2) Uji Homogenitas Data Pre Test

Setelah diketahui kedua sampel berdistribusi normal, maka selanjutnya adalah melakukan uji homogenitas yang pada penelitian ini uji homogenitas menggunakan Uji-Fisher. Uji ini dilakukan untuk mengetahui apakah sebaran data berasal dari populasi yang homogen atau tidak homogen. Hal ini dapat ditentukan dengan cara membagi varians terbesar dengan varians terkecil dari setiap masing-masing kelas, yang selanjutnya dibandingkan dengan tabel $F$ pada taraf signifikansi $5 \%(\propto=0,05)$. Berdasarkan hasil perhitungan, diperoleh hasil penelitian sebagai berikut.

Tabel 3. Hasil Perhitungan Uji Homogenitas Fisher Pretes

\begin{tabular}{cccc}
\hline Kelas & Nilai $\boldsymbol{F}_{\text {hitung }}$ & Nilai $\boldsymbol{F}_{\text {tabel }}$ & Keputusan \\
\hline Eksperimen-Kontrol & 0,66 & 1,98 & Homogen \\
\hline
\end{tabular}

Dari tabel di atas dapat terlihat bahwa nilai $F_{\text {hitung }}<$ nilai $F_{\text {tabel }}$ yaitu $0,66<$ 1,98. Dengan demikian, dapat disimpulkan bahwa data pre test atau tes awal kemampuan menulis karangan argumentasi siswa terutama menulis kelas eksperimen dan kelas kontrol berasal dari populasi yang homogen. 


\section{Supyan Sori}

Pengaruh Model Pembelajaran Berbasis Masalah terhadap Kemampuan Menulis Karangan Argumentasi Siswa Kelas IX SMP Muhammadiyah 1 Kota Tangerang

\section{3) Uji Homogenitas Data Post Test}

Setelah diketahui ke dua sampel baik kelas eksperimen maupun kelas kontrol berdistribusi normal, maka selanjutnya dilakukan Uji Homogenitas dengan Uji Fisher. Tujuan dari dilakukannya Uji Homogenitas ini adalah untuk mengetahui apakah data postes dari ke dua kelas berasal dari populasi yang homogen atau tidak. Sama halnya dengan data pretes, untuk mengetahui hasil Uji Homogenitas data postes dilakukan dengan cara membagi varians terbesar dengan varians terkecil dari setiap masingmasing kelas, yang selanjutnya dibandingkan dengan tabel $\mathrm{F}$ pada taraf signifikansi $5 \%(\propto=0,05)$. Hasil perhitungan uji homogenitas untuk data postes dapat dilihat pada tabel sebagai berikut.

Tabel 4. Hasil Perhitungan Uji Homogenitas Fisher Postes

\begin{tabular}{cccc}
\hline Kelas & Nilai $\boldsymbol{F}_{\text {hitung }}$ & Nilai $\boldsymbol{F}_{\text {tabel }}$ & Keputusan \\
\hline Eksperimen-Kontrol & 1,88 & 1,98 & Homogen \\
\hline
\end{tabular}

Dari tabel di atas dapat terlihat bahwa nilai $F_{\text {hitung }}<$ nilai $F_{\text {tabel }}$ yaitu $1,88<1,98$. Dengan demikian, dapat disimpulkan bahwa data post test atau tes akhir kemampuan menulis bahasa Indonesia siswa terutama karangan argumentasi kelas eksperimen dan kelas kontrol berasal dari populasi yang homogen.

\section{b. Pengujian Hipotesis}

\section{1) Uji T-test Data Pre Test}

Berdasarkan hasil perhitungan bahwa baik kelas eksperimen dan kelas kontrol memiliki data yang berdistribusi normal serta berasal dari populasi yang homogen, maka statistik yang digunakan adalah statistik parametris. Pengujian hipotesis untuk data pre test pada penelitian ini menggunakan uji T-test atau uji perbedaan dua ratarata yang bertujuan untuk mengetahui apakah terdapat perbedaan rata-rata skor kemampuan awal keterampilan menulis siswa antara kelas eksperimen dengan kelas kontrol. Untuk uji $T$ pada data pre test menggunakan uji $T$ dua pihak dengan memakai rumus The pooled variance model t-test pada taraf signifikansi $5 \%(\propto=0,05)$. Hasil perhitungan pengujian hipotesis untuk data pre test dapat dilihat pada tabel di bawah ini.

Tabel 5. Hasil Perhitungan Uji T-test Pretes

\begin{tabular}{cccc}
\hline Kelas & Nilai $\boldsymbol{t}_{\text {hitung }}$ & Nilai $\boldsymbol{t}_{\text {tabel }}$ & Keputusan \\
\hline Eksperimen-Kontrol & $-0,0063$ & 2,0084 & $\boldsymbol{H}_{\mathbf{0}}$ diterima \\
\hline
\end{tabular}

Berdasarkan tabel di atas, dapat terlihat bahwa data hasil penelitian pre test diperoleh nilai $t_{\text {hitung }}<$ nilai $t_{\text {tabel }}$. Dengan demikian sesuai dengan pengajuan hipotesis, untuk uji $T$ data pre test dapat disimpulkan bahwa $H_{0}$ diterima atau dapat dikatakan tidak terdapat perbedaan kemampuan pemecahan masalah kemampuan menulis karangan argumentasi siswa antara kelas kontrol dan kelas eksperimen.

Silampari Bisa: Jurnal Penelitian Pendidikan Bahasa Indonesia, Daerah, dan Asing Vol. 4, No. 2, 2021 


\section{Supyan Sori}

Pengaruh Model Pembelajaran Berbasis Masalah terhadap Kemampuan Menulis Karangan Argumentasi Siswa Kelas IX SMP Muhammadiyah 1 Kota Tangerang

\section{2) Uji T-test Data Post Test}

Karena dalam uji prasyarat statistik inferensial menyatakan bahwa data post test untuk kelas eksperimen dan kelas kontrol berdistribusi normal dan berasal dari populasi yang homogen, maka sama halnya dengan pengujian hipotesis pada data pre test, untuk data post test pengujian hipotesis yang digunakan adalah statistik parametrik. Pengujian ini menggunakan uji T-test atau uji perbedaan dua rata-rata yang bertujuan untuk mengetahui apakah terdapat perbedaan rata-rata skor kemampuan keterampilan berbicara siswa setelah diberi perlakuan dengan menggunakan strategi pembelajaran model Pembelajaran Berbasis Masalah (PBM) untuk kelas eksperimen dengan kelas kontrol yang tidak diberi perlakuan model pembelajaran model Pembelajaran Berbasis Masalah (PBM). Untuk uji $T$ pada data pretes menggunakan uji $T$ dua pihak dengan memakai rumus The pooled variance model $t$-test pada taraf signifikansi $5 \%(\propto=0,05)$. Hasil perhitungan pengujian hipotesis untuk data pretes dapat dilihat pada tabel di bawah ini.

Tabel 6. Hasil Perhitungan Uji T-test Post Test

\begin{tabular}{cccc} 
Kelas & Nilai $\boldsymbol{t}_{\text {hitung }}$ & Nilai $\boldsymbol{t}_{\text {tabel }}$ & Keputusan \\
\hline Eksperimen-Kontrol & 0,94 & 2,0084 & $\boldsymbol{H}_{1}$ diterima \\
\hline
\end{tabular}

Berdasarkan tabel di atas, dapat terlihat bahwa data hasil penelitian pre test diperoleh nilai $t_{\text {hitung }}>$ nilai $t_{\text {tabsl }}$. Dengan demikian, sesuai dengan pengajuan hipotesis, untuk uji $T$ data postes dapat disimpulkan bahwa $H_{1}$ diterima atau dapat dikatakan terdapat perbedaan kemampuan keterampilan menulis siswa antara kelas eksperimen yang diberi perlakuan model pembelajaran PBM, dengan siswa kelas kontrol yang tidak diberi model pembelajaran PBM.

\section{Pembahasan}

Berdasarkan hasil perhitungan analisis penelitian data pre test atau tes awal baik dari kelas kontrol maupun kelas eksperimen dengan menggunakan uji $T$ dua pihak menunjukkan bahwa kemampuan awal siswa ke dua kelas tersebut dalam kemampuan menulis karangan argumentasi bahasa Indonesia siswa terutama menulis tidak berbeda secara signifikan pada taraf signifikansi $5 \%(\propto=0,05)$. Dari hasil perhitungan diperoleh hasil $t_{\text {hitung }}=-0,0063$ sedangkan nilai $t_{\text {tabel }}$ untuk sampel sebanyak 50 orang siswa adalah 2,0084. Hal ini berarti nilai $t_{\text {hitung }}<$ nilai $t_{\text {tabel }}$. Dengan demikian dapat dikatakan bahwa siswa SMP Muhammadiyah 1 Kota Tangerang yang pada penelitian ini kelas IX.PI sebagai kelas kontrol dan siswa kelas IX.PA sebagai kelas eksperimen mempunyai kemampuan menulis karangan argumentasi bahasa Indonesia siswa pada materi menulis yang relatif sama.

Setelah diberikan perlakuan dalam kegiatan pembelajaran yaitu pada kelas eksperimen diberikan pembelajaran dengan model pembelajaran berbasis masalah (PBM) dan kelas kontrol diberikan pembelajaran dengan tidak memakai model pembelajaran berbasis masalah (PBM) seperti kegiatan pembelajaran konvensional (ceramah) dan tanya jawab. Sehingga diperoleh data postes atau tes akhir yang kemudian dianalisis dengan menggunakan uji $T$ dua pihak, memberikan hasil bahwa siswa yang diberikan perlakuan pembelajaran model pembelajaran PBM lebih 


\section{Supyan Sori}

Pengaruh Model Pembelajaran Berbasis Masalah terhadap Kemampuan Menulis Karangan Argumentasi Siswa Kelas IX SMP Muhammadiyah 1 Kota Tangerang

mengalami peningkatan dibandingkan dengan siswa yang tidak diberikan strategi pembelajaran PBM. Hal ini dapat dilihat dari hasil perhitungan, bahwa nilai $t_{\text {hitung }}>$ nilai $t_{\text {tabel }}$ dengan perolehan $t_{\text {hitung }}=0,94$ sedangkan untuk $t_{\text {tabel }}=2,0084$. Hal ini berarti sesuai dengan pengajuan hipotesis dan dapat ditarik kesimpulan bahwa terdapat perbedaan kemampuan menulis karangan argumentasi siswa antara siswa yang diberi model pembelajaran PBM dengan siswa yang tidak diberi model pembelajaran PBM. Hal ini membuktikan bahwa model pembelajaran berbasis masalah bukan saja mampu berpengaruh dalam meningkatkan kemampuan menulis teks deskripsi siswa (Sakila, 2019), kemampuan menulis karangan narasi (Iman, 2018)), kemampuan menulis teks prosedur kompleks (Frince S, 2018), tetapi berpengaruh juga meningkatkan kemampuan menulis karangan argumentasi siswa kelas IX SMP Muhammadiyah 1 Kota Tangerang.

Beberapa temuan yang terlihat dari proses penelitian yang menunjukkan bahwa pembelajaran dengan model pembelajaran PBM lebih mengalami peningkatan karena orientasi pada pembelajaran dengan model pembelajaran PBM adalah aktivitas siswa bukan hanya pada jawaban atu hasil akhir. Selain itu, pembelajaran dengan model pembelajaran PBM tidak berpusat pada guru sebagai pendidik, melainkan memberikan kebebasan kepada siswa untuk menyampaikan pendapat atas apa yang menjadi permasalahan yang disajikan. Dalam pembelajaran PBM juga siswa disajikan masalah yang bersifat terbuka, sehingga siswa melalui diskusi dengan kelompoknya dapat terlatih untuk menyelesaikan masalah dengan beberapa cara atau strategi yang dianggapnya benar. Oleh karena itu, siswa yang mendapat perlakuan pembelajaran dengan model pembelajaran PBM kemampuan menulis karangan argumentasi siswa pada materi menulis lebih mengalami peningkatan yang signifikan dibandingkan kelas yang diberi perlakuan dengan model pembelajaran konvensional (ceramah). Sehingga siswa pada kelas eksperimen setelah diberikan perlakuan, dapat menulis karangan argumentasi dengan baik sesuai struktur karangan argumentasi yang baik dan benar.

\section{Simpulan dan Saran}

Berdasarkan rumusan masalah, hasil penelitian, dan pembahasan dalam penelitian ini, dapat disimpulkan bahwa hasil pre test kedua kelas sebelum diberikan pembelajaran diperoleh hasil bahwa $t_{\text {hitung }}-0,0063<2,0084 t_{\text {tabel }}$, maka Ho diterima yang artinya tidak terdapat perbedaan hasil belajar Karangan Argumentasi siswa sebelum diberikan perlakuan dengan menggunakan model pembelajaran berbasis masalah (MPBM).

Hasil post test pada kedua kelas setelah diberikan pembelajaran diperoleh hasil bahwa $t_{\text {hitung }} 0,94>2,0084 t_{\text {tabel}}$, maka Ho juga diterima yang artinya tidak terdapat perbedaan hasil belajar karangan argumentasi siswa sebelum diberikan perlakuan dengan menggunakan model pembelajaran berbasis masalah (PBM). Kemampuan menulis karangan argumentasi siswa kelas IX SMP Muhammadiyah 1 Kota Tangerang meningkat setelah mengikuti pembelajaran dengan menggunakan model pembelajaran berbasis masalah (PBM). Peningkatan ini terlihat dari perubahan nilai rata-rata. Pada kelas eksprimen rata-rata peningkatan sebesar 76,16 termasuk dalam kategori sedang. Sedangkan pada kelas kontrol rata-rata peningkatan berada pada katagori rendah yaitu sebesar 67,94. Dengan demikian, dapat disimpulkan bahwa 


\section{Supyan Sori}

Pengaruh Model Pembelajaran Berbasis Masalah terhadap Kemampuan Menulis Karangan Argumentasi Siswa Kelas IX SMP Muhammadiyah 1 Kota Tangerang

pembelajaran menggunakan model pembelajaran berbasis masalah (PBM) dapat memberikan pengaruh lebih baik terhadap hasil belajar menulis karangan argumentasi. Pengaruh nilai tes kemampuan menulis ini meliputi seluruh aspek kemampuan menulis karangan argumentasi yang dijadikan kriteria penilaian.

Berdasarkan pembahasan dan simpulan di atas, penulis memiliki saran sebagai berikut, hendaknya para guru bahasa Indonesia hendaknya lebih kreatif dalam menentukan strategi pembelajaran dalam meningkatkan kemampuan menulis siswa agar siswa tidak merasa jenuh pada saat mengikuti pembelajaran dalam kelas. Model pembelajaran PBM terbukti mampu meningkatkan kemampuan menulis karangan argumentasi siswa. Oleh karena itu, para guru bahasa Indonesia dapat menjadikan model pembelajaran PBM ini sebagai salah satu alternatif untuk meningkatkan kemampuan menulis siswa.

\section{Daftar Pustaka}

Dalman, H. (2014). Keterampilan Menulis. Jakarta: PT Raja Grafind Persada.

Frince S., M. (2018). Efektivitas Model Pembelajaran Berbasis Masalah terhadap Kemampuan Menulis Teks Prosedur Kompleks Siswa Kelas X SMK Negeri 13 Medan Tahun Pembelajaran 2013/2014. Edukasi Kultura: Jurnal Bahasa, Sastra Dan Budaya, 1(1). doi:10.24114/kultura.v1i1.11700

Hasibuan, R., \& Hafrison, M. (2020). Komparasi Keterampilan Menulis Teks Laporan Hasil Observasi dengan Keterampilan Menulis Teks Cerita Fantasi Siswa Kelas VII SMP Negeri 22 Padang. Pendidikan Bahasa Indonesia, 9(1), 182. doi:10.24036/108280-019883

Hudhana, W. D. \& Sulaeman, A. (2019). Pengembangan Media Video Scribe dalam Peningkatan Kemampuan Menulis Cerpen Berbasis Karakter Siswa Kelas X SMA se-Kabupaten Tangerang. Pena: Jurnal Pendidikan Bahasa Dan Sastra, 9(1), 31-46. doi:10.22437/pena.v9i1.6839

Iman, I. (2018). Perbandingan Model Pembelajaran Berbasis Masalah dengan Model Inkuiri Terbimbing dalam Pembelajaran Menulis Karangan Narasi pada Siswa Kelas VII SMP Negeri 1 Kadugede. Jurnal Tuturan, 7(1), 814. doi:10.33603/jt.v7i1.1699

Ishak, S. (2014). Cara Menulis Mudah. Jakarta: PT Elex Media Komputindo.

Mulyati, S. (2019). Pengaruh Kemampuan Bernalar dan Penguasaan Kosakata terhadap Kemampuan Menulis Karangan Argumentasi. Diskursus: Jurnal Pendidikan Bahasa Indonesia, 1(01), 71. doi:10.30998/diskursus.v1i01.3514

Rusman. (2012). Model-Model Pembelajaran. Jakarta: PT Raja Grafindo Persada.

Saddhono, K. (2014). Pembelajaran Keterampilan Berbahasa Indonesia. Yogyakarta: Graha IImu. 


\section{Supyan Sori}

Pengaruh Model Pembelajaran Berbasis Masalah terhadap Kemampuan Menulis Karangan

Argumentasi Siswa Kelas IX SMP Muhammadiyah 1 Kota Tangerang

Sakila, S. (2019). Metode Pemecahan Berbasis Masalah pada Pembelajaran Menulis Teks Deskripsi. Genta Bahtera: Jurnal Ilmiah Kebahasaan dan Kesastraan, 5(1), 1-17. doi:10.47269/gb.v5i1.77

Shoimin, Aris (2014). 68 Model Pembelajaran Inovatif dalam Kurikulum 2013. Yogyakarta: Ar-Ruzz Media.

Sugiyono. (2011). Metode Penelitian Kuantitatif dan Kualitatif dan R\&D. Bandung: CV ALFABETA.

Sulaeman, A. \& Goziyah, G. (2019). Metodologi Penelitian Pendidikan Bahasa dan Sastra. Jakarta: Edu Pustaka.

Suparno \& Yunus, M. (2012). Keterampilan Dasar Menulis. Jakarta: Universitas Terbuka.

Susanto, A. (2015). Teori Belajar dan Pembelajaran di Sekolah Dasar. Jakarta: Prenada Media.

Tan, Oon-Seng. (2003). Problem Based Learning Innovation: Using Problem to Power Learning in 21st Century. Singapore: Thompson Learning.

Tarigan, H. G. (2008). Menulis Sebagai Suatu Keterampilan Berbahasa. Bandung: Angkasa.

Trianto. (2007). Model-Model Pembelajaran Inovatif Berorientasi Konstruktivistik. Jakarta: Prestasi Pustaka.

Zainurrahman. (2013). Menulis: Dari Teori Hingga Praktik (Penawar Racun Plagiarisme). Bandung: Alfabeta.

Silampari Bisa: Jurnal Penelitian Pendidikan Bahasa Indonesia, Daerah, dan Asing

Vol. 4, No. 2, 2021 